\title{
The Influence of Development on Managerial Capabilities and Performance: Empirical Evidence from Pakistan
}

\author{
Kazi Afaq Ahmed \\ Institute of Business Management, Karachi, Pakistan \\ afaqkazi@yahoo.com
}

Received date: 5 September 2016; Accepted date: 19 December 2016; Published date: 12 May 2017

Academic Editor: Arshad Ahmad

Copyright (C) 2017. Kazi Afaq Ahmed. Distributed under Creative Commons CC-BY 4.0

\begin{abstract}
"What people respect about the companies is not how they are structured or their specific approaches to management, but their capabilities. You can't see or touch them, yet they can make all the differences in the world when it comes to market value and give investors confidence in future earnings" Smallwood \& Ulrich (HBR 2004). The purpose of this study was to investigate the influence of "development, on creating superior managerial capabilities that impact on organizational performance". The study findings revealed "Two link value chain relationship: development creating managerial capabilities and managerial capabilities creating performance". This value chain relationship was tested in the context of size and ownership of the organization and found interesting empirical evidence: Multinational and large sized Pakistani organizations create learning culture and invest on development that enhance their managerial capabilities leading to improved performance although there is no direct relation between size and ownership of the organization with managerial capabilities and performance. Small sized Pakistani organizations lack development framework and learning culture that adversely influence the development of managerial capabilities; leading to poor managerial performance and overall firm performance and sustainability. The organizations focusing on development: creating learning culture, investing on capacity building, and empowering managers to take managerial decisions, are more likely to have superior managerial capabilities. The organizations can capitalize on superior managerial capabilities and make them imitable competitive advantage over their competitors. The study finding can be used to develop consultancy framework for performance improvement.
\end{abstract}

Keywords: Managerial Capabilities, Development, Performance, Learning Culture

\section{Introduction}

The resource-based view of the firm (RBV) and the resultant resource-based theory
(RBT) provide an important frame-work for explaining and predicting the basis of a firm's competitive advantage and performance; Barney et al. (2011); 
Slotegraaf et al. (2003); Vorhies and Morgan (2005). The term resources of the firm can be divided into " Resources " and "Capabilities", the resources are extrinsic and tradable, can be acquired and easy to duplicate and exchange. The tangible resources, that are rare, controlled by the firm and costly to replace for the competition can only be short-term competitive advantage. The capabilities are special type of intangible resource, organizational embedded, firm specific, and non transferable. The capabilities of the organization are evolved, build, and represent the personality of the organization that is imitable and difficult to replace for the competition.

"The fast emerging global economy, increasing competition and volatile environment have posed new challenges, and increased the importance of developing scarce and imitable resources: organizational capabilities" Collis \& Montgomery, (1995); Hamel, 1994; Prahalad \& Hamel, (1990), that could be the sustainable competitive advantage. The previous research studies revealed that Human Resources interventions and system have influence on the performance of the organizations and businesses, Richardson and Thompson 1999, Cooper (2000).

An article of Harvard Business Review "Capitalizing on Capabilities" discussed different management capabilities and their importance. It suggests that the companies are not valued for their structure, management style, and approaches: companies are respected for their capabilities, capacity to innovate and quality of intangible resources and determine the personality of the organization. The superior managerial capabilities are attained as a result of investment on developing the managerial skills and knowledge of people, providing a learning culture, empowering them and providing managerial context where managers have freedom to take their professional decisions.

Although earlier research work is available, that depicts the relationship between development, managerial capabilities and managerial performance; however, organizational performance in the context of the organizations operating in the developed countries could not be traced.

The organizations are giving more importance and investing on tangible assets of the organization to improve performance and ensure sustainability of the organizations. There is relatively limited attention paid to invest on developing the managerial capabilities that directly influence performance. The organizations are not giving due attention to internal environment and inculcating the learning culture that have direct impact on building the superior managerial capabilities. The local family businesses and organizations lack the appropriate understanding of the importance of the managerial capabilities and their impact on organizational performance. They are reluctant to invest on building the capabilities of the people and creating the learning environment where people can learn and develop effectively that impact on the performance of the organization. The motivation behind this research study was to find the empirical evidence in respect of the relationship between development and capabilities, enabling the entrepreneurs, corporate leaders and Human Resources professionals to understand the impact of development on performance. There are always arguments and burning questions in respect of the impact of training and development on the performance of the organization, during the business planning meetings and performance review. Thus, the study finding will help the HR professionals to develop the performance improvement framework using development as a tool.

\section{Problem Statement}

There is a relationship between managerial capabilities, managerial performance and organizational performance. However, we could not trace the previous studies on value chain relationship between development, managerial capabilities, and performance in the context of organizational size, and ownership in the developing countries. 
Earlier research work has determined that managerial capabilities depend on managerial knowledge and managerial skills. (Abraham et al., (2000); Adner \& Helfat, (2003); Caldeira \& Ward, (2003). Bailey \& Helfat, (2003); Carmel \& Tishler, (2004); Henderson, (2003); Holley et al., (2005); Winter, (2003) Suggested the corelation between managerial capabilities and managerial performance. However, there was a need to deeply examine the impact of development on managerial capabilities and performance to test the validity of value chain relationship.

\section{Significance of study}

The research study results will be helpful to develop the consultancy framework to improve performance, by using development (learning culture, management development, managerial context and managerial discretion) as a tool to create superior managerial capabilities. This study results will provide a strong argument to HR professionals and management to justify the investment on developing "capabilities".

\section{Objective of study}

The objective of the research study was to examine the relationship between development, managerial capabilities and managerial performance and its influence on the overall organizational performance: in the context of size of the organization and ownership.

\section{Previous work}

\section{Managerial Capabilities}

Penrose (1959: 46) argued that the managerial skills and managerial knowledge of the individuals are integrated to achieve the managerial capabilities of the company. When the individual capabilities are combined and pooled up, they can deliver better results as a team and provide additional services. He further stated that every individual as a member of the team, can capitalize upon each other's strengths, skills and knowledge, take the advantage of the environment and the system and achieve enhanced productivity.
Sanchez and Heene (1996) said that the managers as a group, when they continue working together and capitalizing on each other's knowledge and skills, their collective wisdom, and capabilities available to the organization, become permanent and together with the communication, learning culture, and development, determine the personality of the organization, In the study conducted by Boeker \& Karichalil (2012), they stated that developing managerial capabilities is necessary for growth.

Lado, Boyd, and Wright (1992) further argued that organizations by attaining superior managerial capabilities create the capacity: to create vision, formulate strategies, and make them work by communicating to the workforce dner \& Helfat, 2003; Caldeira \& Ward, 2003; Helfat \& Peteraf, 2003). Their prior research indicates that the manager's knowledge \& skills are the bases of managerial capabilities. The organizations are required to continue investing on developing the knowledge and skills to attain superior managerial capabilities that can be used by the organizations to improve performance (Mahoney, (1995: 92). In "The Management of Resources and Resource of Management", Mahoney, 1995: 92) discussed that the effectiveness of the management team depends on their managerial capabilities, skills and personal attributes that are critical, and are required to have sustainable competitive advantage in the market.

This uncertainty poses numerous challenges for managers, policymakers and researchers, (Teeter, Preston; Sandberg and Jorgen (2016) for we still have a poor understanding of how such uncertainty affects organizational responses and the ability of organizations to generate unique capabilities.. The senior management of the organizations needs to have a broad set of complementary skills available. Any individual employee, argued by Barney and Mahoney (1991,1995), no matter how competent, can not have all managerial skills required to operate the complex operations of the business; therefore, organizations build and develop all required capabilities to attain superior 
managerial capabilities. Therefore, the following hypotheses were derived:

H1: Organizations need to develop managerial knowledge and skills to attain superior managerial capabilities, irrespective of size and ownership of the organization.

H-2: Development variables: learning culture, management development, managerial context and managerial discretion positively influence managerial capabilities.

\section{Performance}

The management capabilities have significant impact on performance (Suci, 2009); if an entrepreneur has good management capability, they can increase performance.

Collis (1994:145) defines organizational capabilities "as the socially complex routines that determine the efficiency with which firms physically transform inputs into outputs" which means organizational capabilities are embedded in the routines of a firm, they reflect the system of an organization and are part of the company's culture and the employee's' networks. As defined by Winter (2003:991), the organizational capability is "a high-level routine (or collection of routines) that, together with its implementing input flows, confers upon an organization's management a set of decision options for producing significant outputs of a particular type."

Collis (1994: 145-146) claims that superior managerial capabilities "allow firms to more efficiently and effectively choose and implement the activities necessary to produce and deliver a product or service to customers." Choi and Shepherd, (2004: 381) denote that Managerial capability is skills, knowledge, and experience of a firm, to be able to handle difficult and complex tasks in management and production. The study of the concept of capability studied at organizational level has revealed its link with the performance of the business, by Niemelä, (2004).
Bailey \& Helfat, 2003; Carmel \& Tishler, 2004; Henderson, 2003; Holley, Greenley, Cadogan, \& Fahy, 2005; Winter, 2003 explained that there is a relationship between capability of the organization and performance, since the managerial capability of the organization is a capability therefore, managerial capability has a relation with performance.

The importance of intangible resources has been emphasized by the authors of the literature on strategic management (Collis, 1994; Hamel \& Prahalad, 1996; Prahalad \& Hamel, 1990; Wernerfelt, 1984, 1995), Therefore, human resources plays an important role in the competitiveness of a company (Aragón-Sanchez \& SanchezMartin, 2005). The above discussions lead to the following hypothesis:

H- 3: Managerial capabilities have significant effect on performance, irrespective of size and ownership of the organization.

\section{Development}

Learning Culture: Denison, (1990, p. 2) defines the organizational culture as "underlying values, beliefs, and principles that serve as foundation for the organization's management system as well as the set of management practices and behaviors that both exemplify and reinforce those basic principles". While \& Hall (1992) are of the view that, "organizational culture serves as a function to explain the type of activity that the organization is engaged upon and the lifecycle stage that the organization has reached".

Organizational culture plays an important role in successful knowledge management. The organizations are required to establish an appropriate culture to encourage people to create and share knowledge within an organization Eppler \& Sukowski, (2000). Klein, Masi, and Weidner (1995) discussed that the organizational culture is the core to improve its products and services quality, and overall effectiveness.

Organizational culture applies to the organization as a whole, in the way it sets 
organization apart from others and also binds its members together. Hence, Hall, (1993) argued that in order to be a contributor to the competitive advantage, the organizational culture of an organization requires a higher quality standard in perception, and a high level of abilities to change, to react to challenge, and to learn from the external environment and the internal organization.

Many strategic researchers have studied the role of organization culture to create competitive advantage. As Barney (1986) for example, who claimed organizational culture as valuable, rare, and imperfectly imitable resources, which is a source of sustainable competitive advantage. The learning culture being crucial to management effectiveness is widely understood, and a large literature exists on the 'learning organization' and the nature of organizational culture. Kilmann (1996) defines a learning organization as: a learning organization describes, controls and improves the processes by which knowledge is created, acquired, distributed, interpreted, stored, retrieved and used, for the purpose of achieving long-term organizational success.

Managerial Development: The development of management and leadership team capabilities contributes significantly toward performance (MLDRN) (LMU) of the DfES and DTI. DTZ (1998) examined 127 firms that were using TEC (Training and Enterprise Council) related management development activity. $63 \%$ of firms could identify an impact of this development on business performance.

H-4: Learning culture is crucial to managerial effectiveness, in both multinational and local organizations.

H-5: Development creates managerial capabilities and managerial capabilities create performance.

H-6: Managerial capabilities and performance has no relation with the size and ownership of the organization.

\section{Methodology}

The structured questionnaire was adopted to get the structured and standardized responses for statistical analysis purposes. The survey method and face-to-face interview approach was used. The interview technique was found effective and delivered good results because it provided opportunity to the researchers to probe and get right answers. The questionnaire comprised of total 47 questions divided into three sections: 1) Managerial Capabilities (managerial knowledge \& skills), 2) Development (learning culture, management development, managerial discretion, managerial context) and, 3) Managerial Performance.

The random sampling technique was used in selection of the sample organizations that included the organizations from manufacturing and service sector. The data were collected from the organizations that included local and multinational organizations, representing small, medium and large size organizations. The respondents' sample was also selected on random basis the respondent were selected from senior management, middle management and junior level to ensure the feedback from all level of management.

\section{Findings \& Discussions}

The perception survey responses were analyzed on the Likert scale using SPSS, and examined; the linkages between various constitutes of development, managerial capabilities and performance, as a result following co-relations have been explored between these variables and their sub variables. The face to face interviews using structured questionnaire also validated the results of the perception survey that has established a structural relationship between; development and managerial capabilities, managerial capabilities and managerial performance, and managerial performance and organizational performance.

The personal interviews and meeting with the people using qualitative techniques also revealed that the organizations having 
learning culture, and investing on people development initiatives, demonstrated better managerial knowledge and skills at work in managing teams, and were found to be effective in achieving the objectives. The perception survey on performance of the organization also revealed that the organizations demonstrated better managerial capabilities, also performed better in terms of their profitability, growth and employee satisfaction. These findings support the resource based view of the organization that organizational capabilities are intangible, rare, non tradable, imitable and difficult to replace for competition thus a sustainable competitive advantage. The organizations with superior managerial capabilities have demonstrated sustained performance and growth trends.

\section{Managerial Capabilities}

A firm achieves its managerial capabilities by integrating the managerial knowledge and skills of individuals, Penrose, (1959: 46). Organizational culture plays an important role in successful knowledge management. The organizations are required to establish an appropriate culture to encourage people to create and share knowledge within an organization, Eppler \& Sukowski, (2000).

The empirical study results (table-1) validated the earlier research work, and determined a strong co-relation between managerial skills and learning culture, and moderate co-relation between learning culture and: managerial context, managerial discretion and managerial development. These results are indicative of the influence of development on managerial capabilities and the existence of a structural relationship between managerial capabilities and development. The organization that creates learning culture, invests on development of managers, develops managers by empowering them, and provides autonomy and freedom to take their own professional managerial decisions, is more likely to have better managerial capabilities. These findings have also confirmed our hypotheses H1 \& H2.

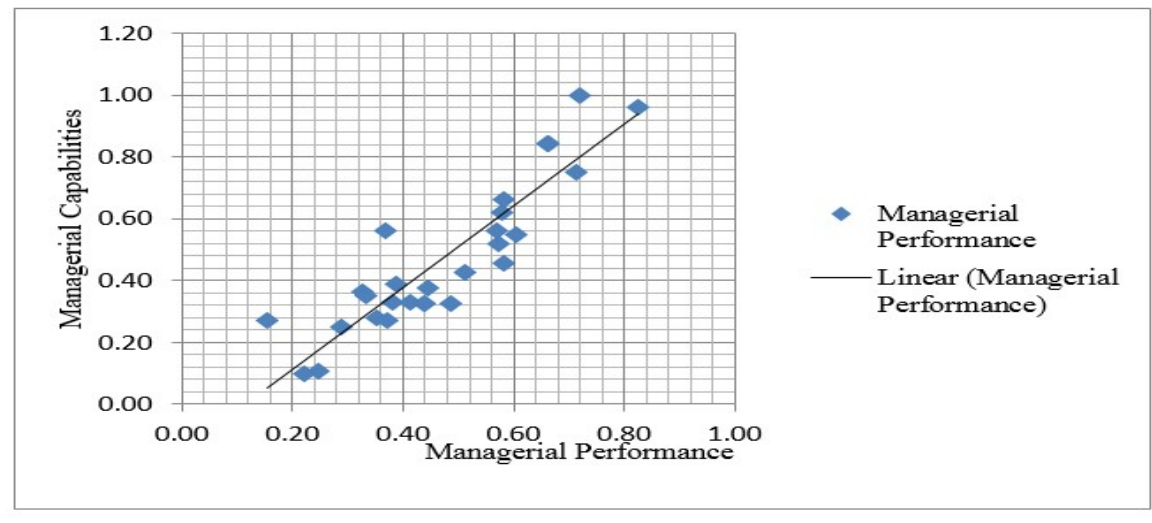

Figure: 1 Managerial performance

Figure: 1 Managerial performance 


\section{Co-Relations}

Table1: Development \& Performance

\begin{tabular}{|c|c|c|}
\hline & Managerial Capabilities & Managerial Performance \\
\hline Managerial Capabilities & 1 & \\
\hline Managerial Performance & 0.899597198 & 1 \\
\hline
\end{tabular}

\begin{tabular}{|l|l|}
\hline Development & Co-Relations \\
\hline Learning Culture \& Managerial Skills & 0.85 -strong \\
\hline Learning Culture \& Managerial Knowledge & 0.35 -week \\
\hline Learning Culture \& Managerial Development & 0.64 -moderate \\
\hline Learning Culture \& Managerial Performance & 0.71 -strong \\
\hline Learning Culture \& Managerial Context & 0.63 -moderate \\
\hline Learning Culture and Managerial Discretion & 0.58 -moderate \\
\hline Performance & Co-Relation \\
\hline Performance \& Managerial Skills & 0.86 -strong \\
\hline Performance \& Managerial Development & 0.90 -strong \\
\hline Performance \& Managerial Discretion & 0.68 -moderate \\
\hline Performance \& Managerial Context & 0.91 -strong \\
\hline
\end{tabular}

\section{Performance}

Management capabilities have significant effect on performance, Suci (2009); if an entrepreneur has good management capability, they will have an effect on increasing performance. The empirical studies depicted the strong co-relation (0.89) between managerial performance and managerial capabilities. The research findings determined that managerial capabilities influence managerial performance leading to overall performance.

The empirical study revealed that the managerial performance has linkage with; managerial skills, managerial development, managerial discretion, and managerial context. The face to face interviews, and observations made during the study depict that those organizations who have developed the managerial skills of their managers, empowered them in taking managerial decisions, and created an environment where they can freely exercise managerial powers using professional knowledge and skills, have shown better performance. The performance indicators: firm profitability, market share, growth and employee satisfaction were found to have positive relation with managerial capabilities and managerial performance. Thus, these findings confirm the existence of a two links values chain relationship between development managerial capabilities and performance. These findings are also supported by the resource based view of 
the organization whereby; the capabilities of the firm are valuable intangible resource, imitable, and difficult to replace, thus a sustainable competitive advantage for the firm.

\section{Development}

The report by the Management and Leadership Development Research Network (MLDRN) for the Leadership and Management Unit (LMU) of the DfES and DTI answers the question, on the basis of the review of existing literature and research, of how confident we can be, on the basis of evidence, that management and leadership development enhance management and leadership capability, and that this in turn contributes to increased performance.

The managerial capabilities have two variables managerial knowledge and managerial skills; the empirical study results revealed that managerial skills are significantly influenced by development variable, learning culture. The results further suggest that the learning culture also has positive influence on managerial performance.
The above results explored a structural relationship between development, managerial capability and performance. The organization creates learning culture, invests on the development of managerial skills and provides empowerment and managerial context, demonstrates better performance that creates superior managerial capabilities. Thus, the hypothesis "The development creates managerial capabilities and managerial capabilities create performance" has been validated.

\section{Large, Medium and Small Organizations}

The objective of the study was to examine the relationship between managerial capabilities and performance in the context of organizational size.

The perception survey results determined that the large organizations have better managerial capabilities as compared to small organizations. The co-relation between the size of the organization and managerial capabilities was also evident from the managerial performance of the people.

Table 3: Large, Medium and Small Size Organizations

\begin{tabular}{|c|c|c|c|}
\hline Factors & Large & Medium & Small \\
\hline Managerial knowledge and experience & 0.54 & 0.49 & 0.56 \\
\hline Managerial skills & 0.59 & 0.55 & 0.4 \\
\hline Organizational learning culture & 0.47 & 0.48 & 0.18 \\
\hline Management development & 0.49 & 0.43 & 0.38 \\
\hline Managerial context & 0.52 & 0.49 & 0.34 \\
\hline Managerial discretion & 0.45 & 0.42 & 0.36 \\
\hline
\end{tabular}




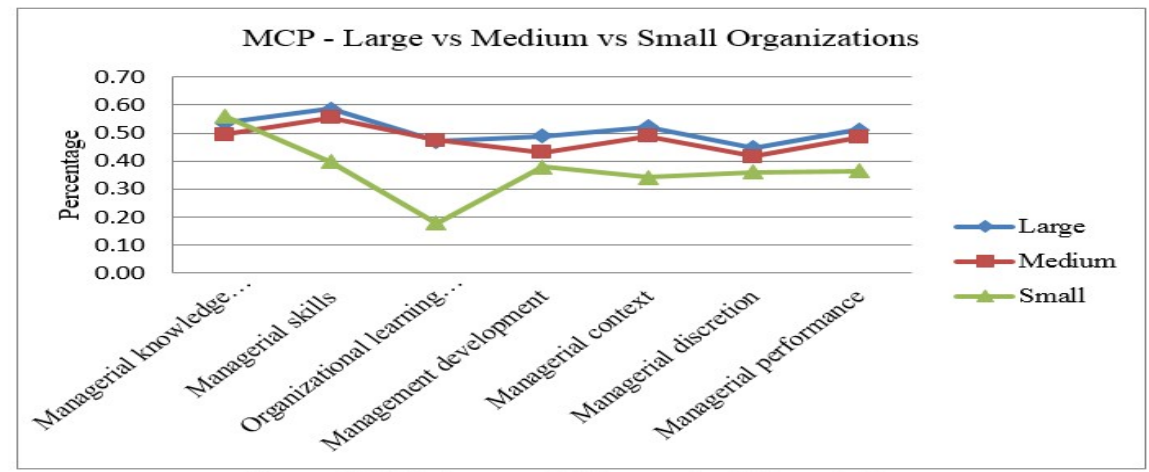

Figure: 2 MCP - Large vs Medium vs Small Organizations

In large organizations, people demonstrated better managerial capabilities and personal attributes as compared to small organizations. The further investigations revealed that large size organizations are more structured and have focus on developing the managerial capabilities. They create learning culture where innovation, creativity and learning initiatives are encouraged, facilitated and appropriately rewarded. The small local organizations lack learning culture and investment on developing managerial capabilities that adversely impact on their performance.

Therefore the hypothesis: "Managerial capabilities and performance has no relation with the size and ownership of the organization" has not been fully accepted. The ownership and size of the organization impact on performance because small organizations are not investing on the development of capabilities. The large organizations invest on development that positively impacts on their managerial capabilities that create higher performance.

\section{Multinational versus Local Companies}

The objective of the study was to examine the co-relation between managerial capabilities, development and performance in the context of organizational ownership (local vs. multinational).

Table 4: Multinational vs. Local organization

\begin{tabular}{|c|c|c|}
\hline Factors & MNC & Local \\
\hline $\begin{array}{c}\text { Managerial knowledge and } \\
\text { experience }\end{array}$ & 0.47 & 0.57 \\
\hline Managerial skills & 0.59 & 0.52 \\
\hline Organizational learning culture & 0.5 & 0.38 \\
\hline Management development & 0.47 & 0.45 \\
\hline Managerial context & 0.55 & 0.43 \\
\hline Managerial dis cretion & 0.46 & 0.39 \\
\hline Managerial performance & 0.54 & 0.44 \\
\hline
\end{tabular}




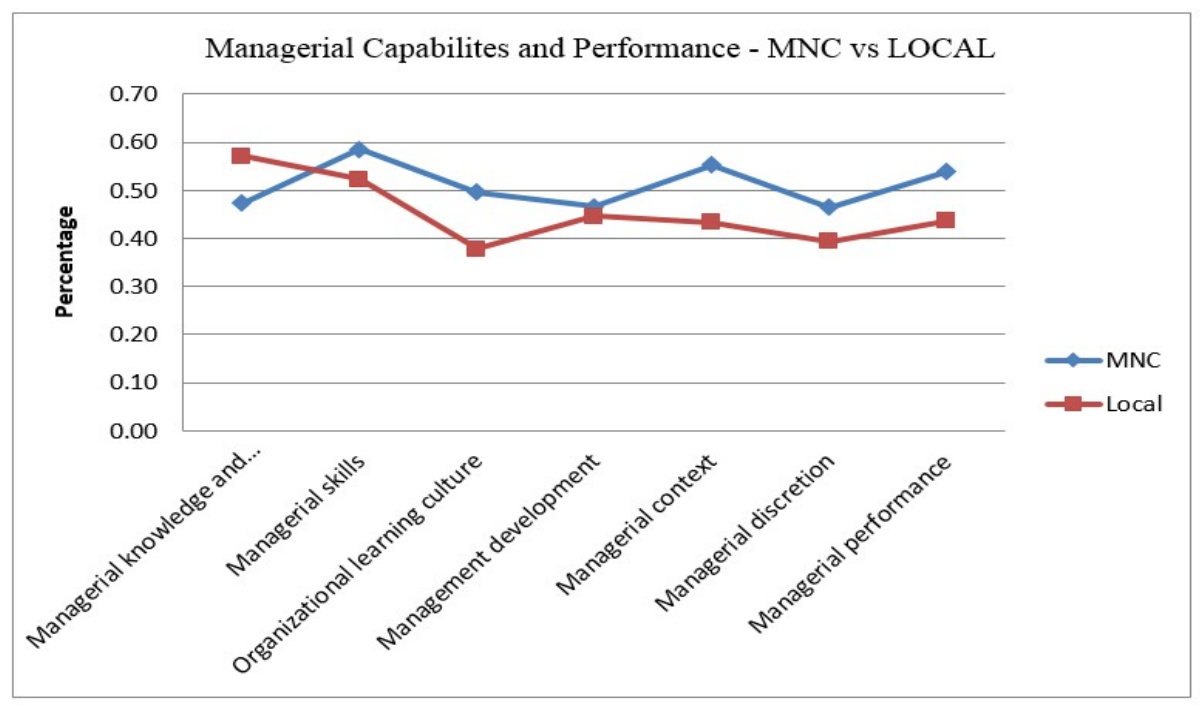

Figure: 3Managerial Capabilities and Performance - MNC vs LOCAL

The study results identified three critical areas lacking in local organizations: learning culture, managerial discretion and managerial context. The local organizations are not investing on the development of the capabilities and lack learning culture. The managers are not fully empowered, managerial context is lacking and authority is more centralized and controlled. Interestingly, the survey results also determined a co-relation between performance and development. The multinational companies have learning culture, empowerment and managerial context that positively influence their performance.

Therefore, the hypothesis: "learning culture is crucial to managerial effectiveness, in both multinational and local organizations" has been proved. The comparative analysis validated our earlier findings that: development creating superior managerial capabilities and capabilities creating performance has also been validated.

\section{Conclusion and Implications}

We have examined enormous amount of research work to study the relationship between managerial capabilities and performance and found sufficient evidence of the impact of managerial capabilities on performance. However this study has explored a simple value chain relationship: "development" creating "managerial capabilities" and "managerial capabilities" "creating performance".

This value chain relationship was tested in the context of size and ownership of the organization and found interesting empirical evidence that validated our findings:

Multinational and large organizations create learning culture and invest on development that enhance their managerial capabilities leading to improved performance, although there is no direct relation between size and ownership of the organization with managerial capabilities and performance.

Local and small organizations lack development framework and learning culture that adversely impact on their managerial capabilities, therefore poor managerial performance leads towards declining performance. However, there is no direct relation of the size of the organization with managerial capabilities, and performance.

It is recommended that the empirical study results to be transformed into consultancy framework for performance improvement create superior managerial capabilities by using "development" as a tool, and use 
managerial capabilities to create performance. The managerial capabilities are an intangible resource, could be a sustainable competitive advantage, imitable and difficult to replace. It is suggested that Human Resources should consider using this value chain relationship in people development strategic planning process. In view of the limited scope and sample size, further investigation is recommended to study the other factors impacting on performance. It is also suggested to the researcher to examine why small organizations are not inclined to use "development" as a performance improvement tool.

\section{References}

Aragón-Sanchez, A., \& Sanchez-Marin, G. (2005). "Strategic orientation, management characteristics, and performance: A study of Spanish SMEs". Journal of Small Business Management, 43(3), 287-308.

Barney, J. B. (1991). "Firm resources and sustained competitive advantage". Journal of Management, 17, 99-120.

Barney, J., \& Hesterly, W. (2012). Strategic management and competitive advantage: Concepts and cases (4th ed.). New Jersey: Pearson.

Bailey, E., \& Helfat C. E. (2003). “External management succession, human capital and firm performance: An integrative analysis". Strategic Management Journal, 24, 347- 369.

Bourne, MFranco-Santos et al. (2008) The impact of Investors in People on people management practices and firm performance, Centre for Business Performance, Cranfield School of Management.

Collis, D., \& Montgomery, C. (1995). "Competing on re- sources: Strategy in the 1990s". Harvard Business Review, 76(3), 118-128.

Collis, D. J., (1994) "Research Note: How Valuable Are Organizational Capabilities?" Strategic Management Journal, 15143-152.
Choi, Y. R., Shepherd, D. A., (2004) "Entrepreneurs' decisions to exploit opportunities." Journal of Management, 30, 377-395.

Carmeli, A., \& Tishler, A. (2004)." The relationships between intangible organizational elements and organizational performance". Strategic Management Journal, 25, 1257- 1278.

Collis (1994). "How valuable are organizational capabilities?". Strategic Management Journal, 15, 143-152.

Denison, D. R. (1990). "Corporate Culture and Organizational Effectiveness". Administrative Science Quarterly, 29, 5273.

DTI (2000). The future of corporate learning, DTI.

DTI (2001). UK competitiveness indicators , 2nd Edition. DTI.

DTZ Pieda Consulting (1998). "Evaluation of the Business Benefits of Management Development. Research Report No 66. DfEE.

Eppler, M.J., \& Sukowski, O. (2000).” Managing team knowledge: Core processes, tools and enabling factors". European Management Journal, 18(3), 334-341.

Hamel, G. (1994). "The concept of core competence. In G. Hamel \& A. Heene (Eds.)", Competence based competition. New York: Wiley.

Holley, G. J., Greenley, G. E., Cadogan, J. W., \& Fahy, J. (2005). "The performance impact of marketing resources". Journal of Business Research, 58, 18-27.

Hamel, G., \& Prahalad, C. K. (1996). Competing for the future. Cambridge, MA: Harvard Business School Press.

Henderson, J. V. (2003). "Marshall's scale economies". Journal of Urban Economics, $53,1-28$.

Hall, R. (1992). "The strategic analysis of intangible resource". Strategic 
Management Journal, 13(2), 135-144.

Hall, R. (1993). "A framework linking intangible resources and capabilities to sustainable competitive advantage". Strategic Management Journal, 14, 607618.

Klein, A. S., Masi, R. J., \& Weidner, I. C. K. (1995)." Organization culture, distribution and amount of control, and perceptions of quality: an empirical study of linkages. Group and Organization Management", 20(2), 122-148.

Kozlenkova I. V., Samaha S., Palmatier R. W. (2014). "Resource-Based Theory in Marketing," Journal of the Academy of Marketing". Science. 42 (1): 1-21.

Lado, A., Boyd, N., \& Wright, P. (1992). "A competency based model of sustainable competitive advan- tage: Toward a conceptual integration". Journal of Management, 18, 77-91.

Mahoney, J.T. (1995). "The Management of Resources and the Resource of Management". Journal

Makadok, R. (2001). "Toward a Synthesis of the Resource-Based View and Dynamic-Capability Views of Rent Creation". Strategic Management Journal. 22 (5): 387-401.

Niemelä, T. (2004). "Interfirm cooperation capability in the context of networking family firms: The role of power". Family Business Review, 17(4), 319-330.

Prahalad, C. K., \& Hamel, G. (1990, May-
June). The core competence of the corporation. Harvard Business Review, 7991.

Prahalad, C. K., \& Hamel, G. (1990). The core compe- tence of the corporation. Harvard Business Re- view, 68(3), 79-91.

Penrose, E.T. (1959). The Theory of the Growth of the Firm. Oxford: Basil Blackwell.

Richardson, Ray and Thompson, Marc. (1999). The impact of people management practices on business performance: a literature review. Issues in People Management. CIPD.

Sanchez, R. \& A. Heene (1996). 'A Systems View of the Firm in Competence-based Competition.'

Suci, Rahayu Puji, 2009. Peningkatan Kinerja Melalui Orientasi Kewirausahaan, Kemampuan,Manajemen, StrategiBisnis. Jurnal Manjemendan Kewirausahaan, VOL.11, NO. 1, MARET 2009: 46-58 Winter, S. G., (2003) "Understanding Dynamic Capabilities." Strategic Management Journal, 24(10), 991-995.

Teeter, Preston; Sandberg, Jorgen (2016). "Constraining or Enabling Green Capability Development? How Policy Uncertainty Affects Organizational Responses to Flexible Environmental Regulations". British Journal of Management.

Wernerfelt, B. (1995). "A resource-based view of the firm: Ten years after". Strategic Management Journal, 16(3), 171-174. 